\title{
EFFICIENCY OF THE INVESTMENT ACTIVITY OF POLISH COMMUNES IN RURAL AREAS
}

\begin{abstract}
Anna KOBIAŁKA, Department of Economics and Agribusiness, University of Life Sciences in Lublin, ul. Akademicka 13, 20-950 Lublin, Poland, anna.kobialka@up.lublin.pl (corresponding author)

Renata KUBIK, Department of Economics and Agribusiness, University of Life Sciences in Lublin, ul. Akademicka 13, 20-950 Lublin, Poland, renata.kubik@up.lublin.pl
\end{abstract}

The purpose of this paper was to evaluate the efficiency of investment activity in the communes in Poland. The commune is a basic unit of local government in Poland, and rural and urban-rural communes constitute the vast majority of municipalities. Communes in their own name and on their own account carry out public tasks that cover all tasks of local interest, including technical and environmental infrastructure. Despite many researches on the efficiency of communes, there are no studies on selected activities as well as on rural areas only. The nonparametric method of technical efficiency Data Envelopment Analysis (DEA) was used in the study. The inputs and the effects of investment activity of rural and urban-rural communes in 2007-2013 were compared. This period was related to the duration of EU support programs. The study was conducted on the basis of data from the Local Data Bank which is Poland's largest database of the economy, society and the environment. The ranking of investment activity for communes were made based of the calculated average for indicators of efficiency. The studies conducted show that the amount of expenditure incurred on the studied spheres of investment activity of the analyzed communes does not translate into their efficiency. This is connected with the possibility of obtaining additional funds from EU. Information on the use of EU funds for financing the municipal investments were not included in the study due to lack of data before 2010. Among the analyzed rural and urban-rural communes the most efficient ones were located in the Mazowieckie, Świętokrzyskie and Lubelskie voivodships, although they were not fully efficient throughout the considered period. Due to its closeness to the capital, the municipality of Mazowieckie voivodeship belongs to an area with a high degree of urbanization. Communes from the Świętokrzyskie and Lubelskie voivodships belong to regions characterized by a high share of rural areas. The dynamic development of infrastructure is extremely important in terms of divergence between regions of the country.

Keywords, communes, efficiency, investments, bioeconomy

\section{INTRODUCTION}

The development of regions, which is supported by European experiences, is a result of actions undertaken by public authorities or market entities operating in the regions as well as national economic, social, administrative and political conditions (Grosse, 2007). All levels of the territorial government should be held co-responsible for the development of respective regions. Therefore, it is important that the development strategies at the Community, national, regional and local level are linked. In Poland, these assumptions were reflected in the Long-Term National Development Strategy - Poland 2030, which proposes a model of development based on three main pillars: creating grounds for innovation, levelling differences in the development of regions, and building competitive advantage through the use of intellectual capital (Szlęzak, Bojar, 2013). National specializations were determined in the government's document entitled National Smart Specializations, identifying 19 smart specializations grouped in 5 thematic areas. With regard to smart specializations, bioeconomy is indicated as an area supporting development both at a national and regional level (Gralak, 2015). At the voivodeship level appropriate development strategies were prepared identifying the lines for the development of specific regions, and bioeconomy is an area indicated within a smart specialization both at a national and regional level. Most Polish voivodeships indicate issues related to bioeconomy as sectors of economy and scientific and technological specializations (Adamowicz, 2016). Bioeconomy was only indicated as a key specialization in the strategy for Lubelskie voivodeship (UMWL, 2014). Local (commune-level) governments in voivodeships, creating their own development strategies, make direct reference to the strategies of such voivodeships and implement the assumptions in their strategic documents.

The basic operating aim of communes is to satisfy the needs of local communities and create favourable operating conditions for economic entities. Communes, on their own behalf and at their own account, carry out public tasks comprising all tasks of local significance (Act of 8 March, 1990) in the area of technical and social infrastructure, public protection and security as well as spatial and environmental order (Walczak, Kowalczyk ,2010). For the purposes of satisfying the needs of their inhabitants, the communes make use of accumulated funds or their assets and make decisions on the ways of utilizing income and on the amount of expenditure (Czyszkiewicz, 2007). With regard to the aforementioned, it should be stated that investing activities of communes is a significant issue in the context of implementation of assumptions underlying the

Copyright (C) 2017 The Authors. Published by Aleksandras Stulginskis University. This is an open-access article distributed under the terms of the Creative Commons Attribution License (CC-BY 4.0), which permits unrestricted use, distribution, and reproduction in any medium, provided the original author and source are credited. 
concept of bioeconomy as a key development factor - in particular in outlying regions where the development of bioeconomy can stimulate and maintain economic growth. Creating new jobs and aiming at rational utilization of bioresources is particularly significant in rural areas and requires, for example, construction of rural, marine and industrial infrastructure, and a knowledge transfer network (European Commission, 2012). The fundamental area of satisfying the needs of the local community often requires building the elements of infrastructure from scratch. The development of infrastructure is oriented, in the first place, at improving the living conditions of residents but also supports the development of economic activities. Although it provides a chance to increase the future income of the communes, these receipts are indirect and distant in time (KRRIO, 2005). The communes must also undertake decisions on the systematic development and modernization of their assets in order to derive income from such assets. The communes' investments in infrastructure most often refer to the development of infrastructure for the needs of public utility services, and mainly road infrastructure. Expenditure incurred on such investments does not guarantee future income or it generates income limited only to covering the operating costs of the constructed facilities. In addition, future running expenses related to the operation of such facilities will increase and revenues will often be insufficient to cover them.

This paper aims to evaluate the investment efficiency of Polish communes in the period from 2007 to 2013 in connection with the completed term of EU funds programming.

\section{RESEARCH METHODS}

The efficiency of investment activities carried out by the communes was evaluated based on a non-parametric Data Envelopment Analysis (DEA) method, which is a tool for determining the relative efficiency of DMU (Decision Making Units). DEA is a deterministic mathematical programming technique applying Farrell's approach to measuring efficiency (Charnes et al., 1994; Coelli et al., 2005). This method is used to evaluate the efficiency of entities running various activities, both in the public and private sector. This method is also used to analyze charitable organizations or ones pursuing social programmes. DEA (next to Free Disposal Hull - FDH) is one of the methods most frequently used for evaluating efficiency in the public sector (Geys, Moesen, 2009). Its advantages include:

- no necessity to determine the functional relationship,

- possibility to introduce multiple outlays and effects,

- possibility to determine the returns to scale.

Among the analyzed units (DMU) an efficient one is identified for which the ratio of efficiency (TE) is 1 . TE values for other units are lower than 1 - they describe the distance from the efficient unit but are also a measure of non-efficiency.

The study used DEAP software version 2.1 (CEPA, 2017) - effects-oriented variant effects with constant returns to scale (Coelli, 1996).

The analyses employed data from the Local Data Bank which is "Poland's largest database of economy and households, innovations, public finance, society, demography and the environment" (Local Data Bank, 2017) maintained by the Central Statistical Office. Data in the LDB also includes information concerning communes according to the administrative division of Poland. The analysis covered data concerning groups of rural communes and urban-rural communes (excluding cities) from respective voivodeships in 2007 - 2013, in compliance with the completed term of EU funds programming. Two main areas of the investing activities of the communes were identified as supporting the development of bioeconomy. Variables describing inputs and effects in respective areas of the commune's investment activities were selected based on a review of literature related to the scope of studies into the efficiency of territorial government units (Narbón-Pepina, De Witte, 2017; Balaguer-Coll, Priori, 2009; Afonio, Fernandes, 2006; Sampaio De Sousa, Stosic, 2005). Two inputs and four effects were identified (two for each input) and assigned as follows:

1. Investments in road infrastructure:

a) input:

- Public finance; Expenses from the budgets of communes and municipalities with poviat rights; Expenses in Division 600 - Transport and communication; communes excluding municipalities with poviat rights; total; rural communes and urban-rural communes;

b) effect:

- Transport and communication; Public roads; Roads according to surface type, location and ownership; hard-surface roads; out of city roads; local (commune) roads;

- Transport and communication; Public roads; Percentage of public roads with improved hard surface according to location; in rural areas;

2. Investments in infrastructure related to municipal management and environmental protection:

a) input:

- Public finance; Expenses from the budgets of communes and municipalities with poviat rights; Expenses in Division 900 - Municipal management and environmental protection; communes excluding municipalities with poviat rights; total; rural communes and urban-rural communes;

b) effect:

- Environmental status and protection; Municipal wastewater treatment plants; Residents using the services of wastewater treatment plants as \% of the total population; in rural areas;

- Environmental status and protection; Economic aspects of environmental protection, Implementation of investments related to environmental protection and water management in rural areas. 
Another step was the verification of variables by means of coefficients of variation (elimination of quasi-constant variables). The critical value of the coefficient of variation $\mathrm{V}^{*}$ was determined as 0.3 . As a consequence, the variable "Percentage of the length of public roads with improved hard surface according to location" was eliminated. It was replaced with the variable "Transport and communication; Public roads; Bridges according to owners; owned by the commune".

\section{RESEARCH RESULTS}

The values of the ratio of efficiency of investment activities carried out by communes located in rural areas ranged from 0.020 to 1.000 (Tab. 1). The average efficiency of investment activities of the analyzed communes throughout the analyzed period was 0.686 . Considering the average values of the ratio of efficiency in respective years, a gradual increase up to 0.844 can be observed in 2013 , which testifies to the increasing efficiency of utilizing funds. Only two out of sixteen groups of communes did not reach full efficiency in any of the analyzed years.

Table 1. Efficiency indicators of investment activity in surveyed communes according to voivodeship in years 2007-2013

\begin{tabular}{|c|c|c|c|c|c|c|c|c|c|}
\hline \multirow{2}{*}{ Communes from voivodeship: } & \multicolumn{7}{|c|}{ Year } & \multirow{2}{*}{ mean } & \multirow{2}{*}{ ranking } \\
\hline & 2007 & 2008 & 2009 & 2010 & 2011 & 2012 & 2013 & & \\
\hline Dolnośląskie & 0.551 & 0.395 & 0.317 & 0.020 & 0.068 & 0.042 & 1.000 & 0.342 & 16 \\
\hline Kujawsko-pomorskie & 0.159 & 1.000 & 0.635 & 0.426 & 1.000 & 0.471 & 0461 & 0.593 & 12 \\
\hline Lubelskie & 0.391 & 0.717 & 1.000 & 1.000 & 1.000 & 1.000 & 1.000 & 0.873 & 3 \\
\hline Lubuskie & 1.000 & 0.535 & 0.352 & 0.744 & 1.000 & 0.328 & 0.869 & 0.690 & 9 \\
\hline Łódzkie & 0.616 & 1.000 & 0.844 & 1.000 & 1.000 & 0.867 & 0.749 & 0.868 & 4 \\
\hline Małopolskie & 1.000 & 0.728 & 1.000 & 0.378 & 0.533 & 0.299 & 0.650 & 0.655 & 10 \\
\hline Mazowieckie & 1.000 & 1.000 & 1.000 & 1.000 & 1.000 & 1.000 & 0.495 & 0.928 & 1 \\
\hline Opolskie & 1.000 & 0.860 & 0.672 & 0.440 & 0.525 & 0.684 & 1.000 & 0.740 & 8 \\
\hline Podkarpackie & 0.610 & 0.682 & 1.000 & 0.556 & 0.694 & 0.732 & 0.969 & 0.749 & 7 \\
\hline Podlaskie & 0.195 & 1.000 & 0.483 & 0.760 & 1.000 & 1.000 & 0.977 & 0.774 & 6 \\
\hline Pomorskie & 0.442 & 0.272 & 0.461 & 0.373 & 0.560 & 0.510 & 0.869 & 0.498 & 14 \\
\hline Śląskie & 0.633 & 0.231 & 0.659 & 0.036 & 0.060 & 0.086 & 1.000 & 0.386 & 15 \\
\hline Świętokrzyskie & 0.462 & 1.000 & 0.940 & 1.000 & 1.000 & 1.000 & 1.000 & 0.915 & 2 \\
\hline Warmińsko-mazurskie & 0.221 & 0.677 & 0.629 & 0.632 & 0.801 & 0.565 & 0.583 & 0.587 & 13 \\
\hline Wielkopolskie & 0.474 & 0.725 & 0.967 & 0.645 & 1.000 & 0.766 & 0.875 & 0.779 & 5 \\
\hline Zachodniopomorskie & 0.460 & 0.338 & 0.755 & 0.434 & 0.770 & 0.469 & 1.000 & 0.604 & 11 \\
\hline mean & 0.576 & 0.698 & 0.732 & 0.590 & 0.751 & 0.614 & 0.844 & 0.686 & $\mathrm{x}$ \\
\hline
\end{tabular}

Source: own study based on LDB

The overall evaluation of the efficiency of investment activities of communes was presented for the whole period of seven years. Based on the average efficiency ratios recorded in 2007-2013 a ranking of communes situated within respective voivodeships was prepared (Fig. 1). The first rank was assigned to communes in the Mazowieckie voivodeship despite the fact that in 2013 the efficiency index was only 0.495. Based on the results obtained from the DEAP program, it was established that this situation was caused by the increase in both outputs while the effects related to investments in road infrastructure decreased. The communes from the above-mentioned voivodeship, presented in the study, were fully efficient in six out of seven years covered by the study. They are a model of efficient utilization of funds for investment activities supporting the development of bio-economy.

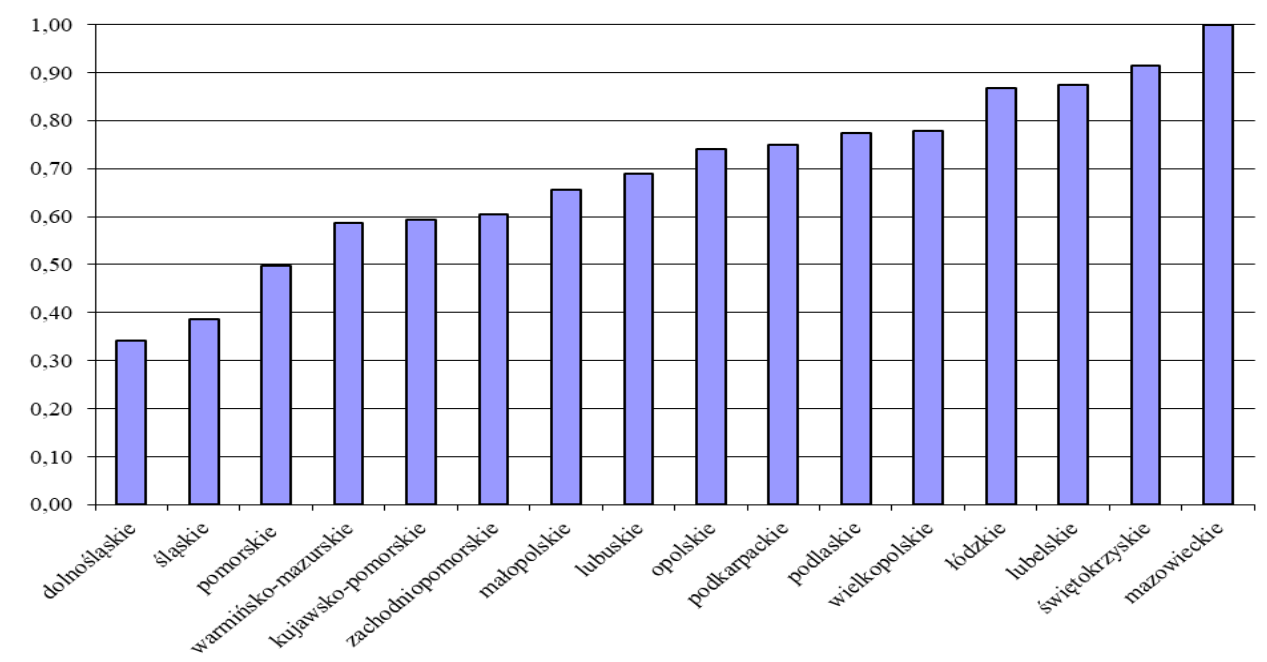

Source: own study

Figure 1. Ranking on efficiency indicators of investment activity in surveyed communes according to voivodeship in years $2007-2013$ 
Data presented in Table 2 indicates that expenditure on the analyzed spheres of investment activities of the said communes is not reflected in their efficiency. Communes situated in the Mazovian voivodeship allocated the highest amount of funds to investment activities compared to other communes analyzed, while in communes situated in Świętokrzyskie and Lubelskie voivodeships, the level of expenditure is less than half and in the analyzed period was not higher than average (PLN 575 million). Communes with expenditure levels similar to communes situated in Świętokrzyskie and Lublin voivodeships, namely, communes from the Zachodniopomorskie and Kujawsko-pomorskie voivodeships, were ranked much lower in the ranking of efficiency of investment activities (respectively $11^{\text {th }}$ and $12^{\text {th }}$ ).

Table 2. Total expenditures (mln PLN) of investment activity in rural and urban-rural communes according to voivodeship in years 2007-2013

\begin{tabular}{|c|c|c|c|c|c|c|c|c|}
\hline \multirow{2}{*}{$\begin{array}{l}\text { Communes from } \\
\text { voivodeship: }\end{array}$} & \multicolumn{7}{|c|}{ Year } & \multirow{2}{*}{ mean } \\
\hline & 2007 & 2008 & 2009 & 2010 & 2011 & 2012 & 2013 & \\
\hline Dolnośląskie & 517.918 & 624.992 & 704.215 & 813.197 & 792.657 & 727.534 & 773.709 & 707.746 \\
\hline Kujawsko-pomorskie & 297.228 & 360,043 & 506.786 & 574.695 & 547.960 & 476.901 & 525.775 & 469.913 \\
\hline Lubelskie & 299.922 & 364.673 & 484.107 & 693.347 & 528.739 & 445.907 & 490.546 & 472.463 \\
\hline Lubuskie & 198.017 & 198.315 & 289.787 & 364.180 & 273.843 & 198.128 & 265.134 & 255.343 \\
\hline Łódzkie & 408.964 & 440.435 & 608.532 & 814.223 & 710.484 & 597.764 & 642.006 & 603.201 \\
\hline Małopolskie & 731.756 & 893.467 & 1105.962 & 1302.692 & 1377.083 & 1181.253 & 1161.468 & 1107.669 \\
\hline Mazowieckie & 989.229 & 1299.226 & 1374.837 & 1505.268 & 1365.287 & 1197.007 & 1279.684 & 1287.220 \\
\hline Opolskie & 245.023 & 241.496 & 333.822 & 394.949 & 357.000 & 285.562 & 317.146 & 310.714 \\
\hline Podkarpackie & 438.115 & 522.177 & 782.351 & 996.337 & 807.051 & 523.118 & 574.890 & 663.434 \\
\hline Podlaskie & 172.758 & 204.319 & 386.107 & 392.146 & 344.294 & 257.187 & 315.825 & 296.091 \\
\hline Pomorskie & 214.918 & 307.993 & 380.984 & 471.598 & 438.411 & 332.752 & 405.021 & 364.525 \\
\hline Śląskie & 407.979 & 462.729 & 600.538 & 650.404 & 627.723 & 556.694 & 593.839 & 557.130 \\
\hline Świętokrzyskie & 219.719 & 274.352 & 466.879 & 555.172 & 492.392 & 385.386 & 383.135 & 396.719 \\
\hline Warmińsko-mazurskie & 190.717 & 210.439 & 291.697 & 413.380 & 383.558 & 294.746 & 314.988 & 299.932 \\
\hline Wielkopolskie & 672.324 & 873.630 & 991.133 & 1094.045 & 1117.609 & 982.405 & 1027.747 & 965.556 \\
\hline Zachodniopomorskie & 296.396 & 351.620 & 448.316 & 532.599 & 523.553 & 446.158 & 550.956 & 449.943 \\
\hline mean & 393.811 & 476.869 & 609.753 & 723.015 & 667.978 & 555.531 & 601.367 & 575.475 \\
\hline
\end{tabular}

Source: own study based on LDB

\section{CONCLUSIONS AND DISCUSSION}

Newly built infrastructure not only contributes to improving the quality of life of the residents of rural areas. Thanks to adequate activities undertaken by the communes, there is a chance that depopulation of such areas will be reduced by improving their investment attractiveness, supporting the development of economic activity. As a consequence, increased investment activities of the communes provide options for their development.

In the analysis of the efficiency of local government units, it was assumed that they can be assessed on the basis of its inputs, effects and processes of transforming inputs into effects. As a result of this measurement, the efficiency of using not only material or financial but also non-measurable inputs (for example human factor) can be assessed. The DEA method also gives the opportunity to compare the efficiency of different units from the same commune segment. Problems that may arise during research are the lack of individual data in all years of analysis.

Based on the studies it can be concluded that the efficiency of utilizing the funds for infrastructural investments is not determined by the amount of expenditure incurred by the communes. This is connected with the possibility of obtaining additional EU financing. Data concerning utilization of EU funds on financing the investments of the communes was not included in this study due to a lack of data from the period preceding 2010.

Among the studied rural and urban-rural communes the most efficient ones were those situated in the area of the Mazowieckie, Świętokrzyskie and Lubelskie voivodeships, although they were not fully efficient at all times throughout the analyzed period. Due to their location in the neighbourhood of a capital city, communes from the Mazowieckie voivodeship are situated in a highly urbanized area. In turn, communes from the Świętokrzyskie and Lubelskie voivodeships are situated in regions characterized by a high share of rural areas. The dynamic development of infrastructure is extremely significant in the context of levelling disparities between the regions of Poland.

\section{REFERENCES}

1. Act of 8 March 1990 on Local Government. Dz.U. 1990, nr 16, poz. 95 z późn. zm. [In Polish]

2. Adamowicz, M. 2016. Bioeconomy as a smart specialization in development strategies of polish regions. Zeszyty Naukowe SERiA Vol. 18(1), pp.10-16.

3. Afonso, A., Fernandes, S. 2006. Measuring local government spending efficiency: evidence for the Lisbon region. Regional Studies, Vol. 40(1), pp. 39-53. https://doi.org/10.1080/00343400500449937 
4. Balaguer-Coll, M.T., Prior, D. 2009. Short- and long-term evaluation of efficiency and quality. an application to Spanish municipalities, Applied Economics, Vol. 41(23), pp. 2991-3002. https://doi.org/10.1080/00036840701351923

5. CEPA Center of Efficiency and Productivity Analysis. Available at http://www.uq.edu.au/economics/cepa/software.php (Accessed on 17/09/2017)

6. Charnes, A., Cooper, W., Lewin, A., Seiford, L. 1994. Data Envelopment Analysis: theory, methodology and application. New York: Springer Science+Business Media Inc.

7. Coelli, T., Prasada Rao, D. S., O`Donnell, Ch., Battesse, G. 2005. An Introduction to Efficiency and Productivity Analysis. Second Edition. New York: Springer Science+Business Media Inc.

8. Coelli, T. 1996. A Guide to DEAP Version 2.1: A Data Envelopment Analysis (Computer) Program. Center for Efficiency and Productivity Analysis (CEPA) Working Papers, No.8/96, pp.43.

9. Czyszkiewicz, R. 2007. Redistribution or Development? The Budget Policy of Local Communities from Zachodniopomorskie Voivodship, Studia Regionalne i Lokalne, Vol. 3 (29), pp. 71-72.

10. European Commission 2012. Innovation for sustainable growth: A bio-economy for Europe Communication From The Commission To The European Parliament, The Council, The European Economic And Social Committee And The Committee Of The Regions, Brussels.

11. Geys, B., Moesen, W. 2009. Measuring Local Government Technical. Efficiency. An application and comparison of FDH, DEA and econometric approaches. Public Performance and Management Review, Vol. 32 (4), pp. 489-504.

12. Gralak, K. 2015. Bioeconomy as an area of regional smart specialization, Polityki europejskie, finanse i marketing, Vol. 14(63), pp. 65-74.

13. Grosse, T. G. 2007. Theory and Practice of Development of Peripheral Regions, Studia Regionalne i Lokalne, Vol.1 (27), pp. 27-49.

14. KRRIO Krajowa Rada Regionalnych Izb Obrachunkowych. 2005. Investment activity of territorial self-government units in the years 1999-2004. Warszawa.

15. LDB Local Data Bank. Available at https://bdl.stat.gov.pl/BDL/dane (Accessed on 17/09/2017)

16. Narbón-Pepina, I., De Witte, K., 2017. Local governments` efficiency: a systematic literature review-part II. International Transactions in Operational Research, pp. 1-30, https://doi.org/10.1111/itor.12389

17. Sampaio, De Sousa, M., Stosic, B. 2005. Technical Efficiency of the Brazilian Municipalities: Correcting Nonparametric Frontier Measurements for Outliers. Journal of Productivity Analysis, Vol. 24(2), pp. 157-181. https://doi.org/10.1007/s11123-005-4702-4

18. Szlęzak, R., Bojar, M. 2013. Innovative development of the Lublin region - a case study of Eastern ICT Cluster. [in:] Innovative regional development, red. M. Bojar, Politechnika Lubelska, Lublin, pp. 78-92.

19. UMWL Urząd Marszałkowski Województwa Lubelskiego. 2014. Development Strategy for Lubelskie Voivodeship for the years 2014-2020 with a perspective to 2030, Lublin.

20. Walczak, M., Kowalczyk, M. 2010. Accounting and budgeting in the financial management of the municipality. Difin, Warszawa, pp. 18. 